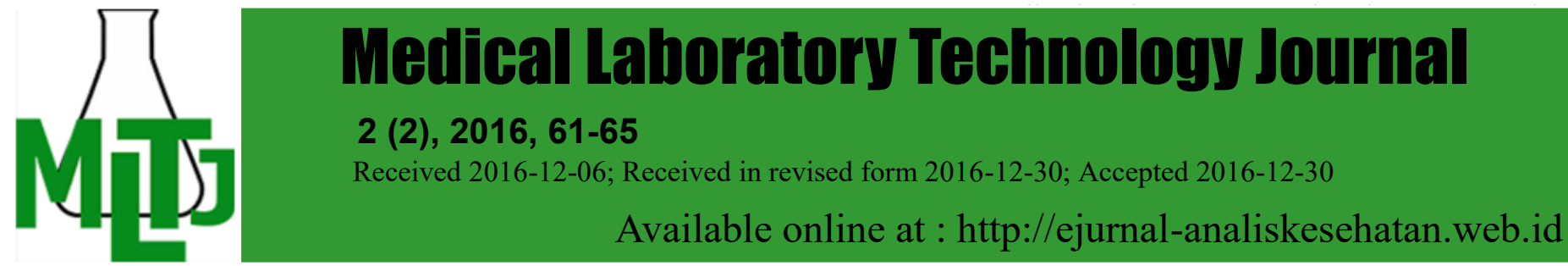

\title{
KETEPATAN HASIL DAN VARIASI WAKTU PENDIDIHAN PEMERIKSAAN ZAT ORGANIK
}

\author{
Haitami, Dinna Rakhmina, Syahid Fakhridani \\ Jurusan Analis Kesehatan Poltekkes Kemenkes Banjarmasin \\ JI Mistar Cokrokusumo 4a Banjarbaru \\ e-mail: haitami4@yahoo.co.id
}

\begin{abstract}
The principle of organic substances determination in water samples is oxidized by an excess amount of $\mathrm{KMnO} 4$, then it is reduced excess amount of oxalic acid, the excess of oxalic acid is titrated back with KMnO4. Based on the procedures in ISO 06-6989.22-2004, a length of boiling time for organic substances determination in water samples is for 10 minutes. This study aimed to determine the effect of boiling time length to the accuracy of the organic substances determination result in water samples. This study was true experiment study with comparative study design. Samples were organic substances, specifically oxalic acid in distilled water in a concentration of $54 \mathrm{mg} / \mathrm{L}$, which was examined for the organic substances level with a boiling time of 5,10 and 15 minutes. The result on each boiling time length consecutively were $52,8 \mathrm{mg} / \mathrm{L} ; 54,5 \mathrm{mg} / \mathrm{L}$; dan $55,1 \mathrm{mg} / \mathrm{L}$. The conclusion of the study was there was effect of boiling time length to the accuracy of organic substances determination result in water samples with the significance value of $0.002(<0,05)$. It is recommended to continue the study using a direct sample from a field with the addition of sample matrix.
\end{abstract}

Keywords: accuracy; boiling; organic substances

Abstrak: Prinsip penetapan zat organik dalam sampel air adalah dioksidasi dengan $\mathrm{KMnO}_{4}$ berlebih, kemudian direduksi oleh asam oksalat berlebih, kelebihan asam oksalat dititrasi kembali dengan $\mathrm{KMnO}_{4}$. Berdasarkan prosedur dalam SNI 06-6989.22-2004 lamanya waktu pendidihan untuk penetapan kadar zat organik dalam sampel air adalah selama 10 menit. Penelitian ini bertujuan untuk mengetahui pengaruh lamanya waktu pendidihan terhadap ketepatan hasil pemeriksaan zat organik dalam sampel air. Jenis penelitian true experiment dengan menggunakan desain comparative study. Sampel penelitian adalah zat organik berupa asam oksalat dalam aquadest yang dibuat dengan konsentrasi $54 \mathrm{mg} / \mathrm{L}$, diperiksa kadar zat organiknya dengan waktu pendidihan 5,10 , dan 15 menit. Hasil penelitian pada setiap lamanya pendidihan secara berurutan yaitu $52,8 \mathrm{mg} / \mathrm{L} ; 54,5 \mathrm{mg} / \mathrm{L}$; dan $55,1 \mathrm{mg} / \mathrm{L}$. Kesimpulan penelitian terdapat pengaruh lamanya waktu pendidihan terhadap ketepatan hasil pemeriksaan zat organik dalam sampel air dengan nilai signifikasi sebesar $0,002(<0,05)$. Disarankan untuk melanjutkan penelitian dengan menggunakan sampel langsung dari lapangan dengan penambahan matrik sampel.

Kata kunci: ketepatan; pendidihan; zat organik 


\section{PENDAHULUAN}

Air adalah kebutuhan dasar bagi kehidupan di muka bumi. Setiap penggunaan air untuk suatu kebutuhan, diperlukan syaratsyarat kualitas air sesuai peruntukannya. Salah satu syarat yang penting adalah ukuran banyaknya zat organik yang terdapat dalam air. Oleh karena itu, penentuan zat organik dalam air menjadi salah satu parameter penting dalam penentuan kualitas air, karena bisa menjadi salah satu ukuran seberapa jauh tingkat pencemaran pada suatu perairan (Febrian, 2008).

Adanya zat organik dalam air menunjukan bahwa air tersebut telah tercemar oleh kotoran manusia, hewan atau oleh sumber lain. Zat organik merupakan bahan makanan bakteri atau mikroorganisme lainnya. Makin tinggi kandungan zat organik didalam air, maka semakin jelas bahwa air tersebut telah tercemar (Asmadi, 2012).

Zat organik adalah zat yang pada umumnya merupakan bagian dari binatang atau tumbuh-tumbuhan dengan komponen utamanya adalah karbon, protein, dan lemak lipid. Zat organik ini mudah sekali mengalami pembusukan oleh bakteri dengan menggunakan oksigen terlarut.

Sisa dari zat organik yang dibuang ke lingkungan disebut juga dengan limbah organik. Limbah organik adalah sisa atau buangan dari berbagai aktifitas manusia seperti rumah tangga, industri, pemukiman, peternakan, pertanian, dan perikanan. Bahan organik biasanya tersusun oleh karbon, hidrogen, oksigen, nitrogen, fosfor, sulfur, dan mineral lainnya. Limbah organik masuk ke dalam perairan dalam bentuk padatan yang terendap, koloid, tersuspensi, dan terlarut. Pada umumnya bentuk padatan akan langsung mengendap menuju dasar perairan, sedangkan bentuk lainnya berada di badan air, baik di bagian yang aerob maupun anaerob. Dimanapun limbah organik berada, jika tidak dimanfaatkan oleh fauna perairan lain seperti ikan, kepiting, bentos (organisme yang hidup di dasar perairan), dan lainnya, maka akan segera dimanfaatkan oleh mikroba, baik mikroba aerobik (mikroba yang hidupnya memerlukan oksigen), mikroba anaerobik (mikroba yang hudupnya tidak memerlukan oksigen), dan mikroba fakultatif (mikroba yang dapat hidup pada perairan aerobik dan anaerobik) (Halim, 2007 dalam Sunawiruddin Hadi dkk, 2014).

Keberadaan zat organik di dalam air men- imbulkan warna dan bau serta dapat membantu pertumbuhan bakteri. Senyawa humus di dalam air akan menimbulkan senyawa trihalometan setelah klorinasi. Telah diketahui bahwa senyawa trihalometan bersifat karsinogenik. Oleh karena itu senyawa organik harus sedapat mungkin disisihkan pada pengolahan air terutama dengan proses kimia (Krisma, 2008).

Analisa zat organik dalam air dapat ditentukan dengan menggunakan metode titrasi permanganometri. Metode titrasi ini menggunakan kalium permanganat yang merupakan oksidator kuat sebagai titran. Titrasi ini didasarkan atas titrasi reduksi dan oksidasi atau redoks. Kalium permanganat telah digunakan sebagai pengoksida secara meluas lebih dari 100 tahun. Reagensia ini mudah diperoleh, murah, dan tidak memerlukan indikator kecuali bila digunakan larutan yang sangat encer. Permanganat beraksi secara beraneka, karena mangan dapat memiliki keadaan oksidasi $+2,+3,+4,+6$, dan +7 (Day \& Underwood, 2002).

Hasil yang diperoleh dinyatakan sebagai nilai permanganat. Nilai permanganat adalah jumlah miligram kalium permanganat yang dibutuhkan untuk mengoksidasi zat organik dalam $1000 \mathrm{~mL}$ air pada kondisi mendidih (SNI 06-6989.22-2004, 2004).

Waktu yang digunakan untuk mendidihkan sampel agar bereaksi sempurna dengan kelebihan $\mathrm{KMnO}_{4}$ sesuai dengan SNI 066989.22-2004 adalah tepat 10 menit. Dari hasil pengamatan di lapangan, kadangkadang waktu pemanasan yang digunakan untuk mendidihkan sampel tidak diperhatikan. Padahal menurut penelitian Farida (2006), pemanasan berpengaruh terhadap hasil pemeriksaan zat organik di dalam sampel air.

Penelitian ini bertujuan untuk mengetahui pengaruh lamanya waktu pendidihan terhadap ketepatan hasil pemeriksaan zat organik dalam sampel air.

\section{BAHAN DAN METODE}

Penelitian ini bersifat true experiment dengan menggunakan desain comparative study (studi perbandingan). Sampel dalam penelitian ini adalah zat organik berupa asam oksalat $\left(\mathrm{H}_{2} \mathrm{C}_{2} \mathrm{O}_{4}\right)$ dalam aquadest yang dibuat dengan konsentrasi $54 \mathrm{mg} / \mathrm{L}$. Jumlah pengulangan pemeriksaan yang dilakukan pada penelitian ini sebanyak 10 kali untuk masingmasing perlakuan. 
Variabel bebas pada penelitian ini adalah lamanya waktu pendidihan. Variabel terikat pada penelitian ini adalah kadar zat organik dalam sampel air.

Sampel dibuat dengan melarutkan zat organik berupa asam oksalat dengan konsentrasi $54 \mathrm{mg} / \mathrm{L}$ dalam 3 liter aquadest. Standarisasi larutan $\mathrm{KMnO}_{4}$ dilakukan dengan larutan $\mathrm{H}_{2} \mathrm{C}_{2} \mathrm{O}_{4}$ 0,01 N. Penetapan Kadar Zat Organik dilakukan dengan cara sampel dipipet 100,0 $\mathrm{ml}$ ke dalam Erlenmeyer yang sudah dicuci. Ditambahkan beberapa tetes larutan baku $\mathrm{KMnO}_{4} \quad 0,01 \mathrm{~N}$ hingga terjadi warna merah muda. Ditambahkan $5 \mathrm{ml} \mathrm{H}_{2} \mathrm{SO}_{4} 4 \mathrm{~N}$. Dipanaskan sampai mendidih 1 menit. Ditambahkan 10,0 ml larutan baku $\mathrm{KMnO}_{4}$ 0,01 N. Kemudian dipanaskan sampai mendidih 10 menit (warna tidak hilang/konstan). Ditambahkan 10,0 ml larutan baku $\mathrm{H}_{2} \mathrm{C}_{2} \mathrm{O}_{4} 0,01$ $\mathrm{N}$. Ditrasi dengan larutan baku $\mathrm{KMnO}_{4} 0,01 \mathrm{~N}$ sampai terbentuk warna merah muda konstan (Hidayati M, Ana dan Yusrin, 2010).Data diperoleh dari hasil kadar zat organik pada sampel dengan lamanya waktu pendidihan 5 , 10 , dan 15 menit.

Untuk menghitung \% Bias digunakan rumus: $\%$ Bias $=(x-\mu) / x$, dimana $x=$ rerata, $\mu=$ nilai target

\section{HASIL DAN PEMBAHASAN Karakteristik Sampel}

Sampel yang digunakan pada penelitian ini adalah sampel zat organik berupa asam oksalat $\left(\mathrm{H}_{2} \mathrm{C}_{2} \mathrm{O}_{4}\right)$ dalam aquadest yang dibuat dengan konsentrasi $54 \mathrm{mg} / \mathrm{L}$.

\section{Hasil Pemeriksaan}

Hasil pengukuran pada masing-masing perlakuan dapat dilihat pada Tabel 1.

Tabel 1. Hasil pengukuran kadar zat organik pada sampel air dengan waktu pendidihan selama 5,10 , dan 15 menit.

\begin{tabular}{cccc}
\hline \multirow{2}{*}{ Pengulangan } & \multicolumn{3}{c}{ Kadar zat organik (mg/L) } \\
\cline { 2 - 4 } & $\begin{array}{c}\text { Pendidihan 5 } \\
\text { menit }\end{array}$ & $\begin{array}{c}\text { Pendidihan } \\
\text { menit }\end{array}$ & $\begin{array}{c}\text { Pendidihan } \\
\text { menit }\end{array}$ \\
\hline 1 & 52,3 & 54,1 & 55,0 \\
2 & 53,6 & 55,7 & 54,3 \\
3 & 52,1 & 55,2 & 55,4 \\
4 & 51,4 & 54,5 & 55,2 \\
5 & 52,5 & 54,3 & 55,2 \\
6 & 52,1 & 53,6 & 55,2 \\
7 & 54,3 & 53,6 & 54,5 \\
8 & 54,3 & 54,5 & 55,0 \\
9 & 52,1 & 55,0 & 55,4 \\
10 & 53,0 & 54,8 & 55,9 \\
\hline Rata-rata & 52,8 & 54,5 & 55,1
\end{tabular}

Uji regresi linier waktu pendidihan terhadap kadar rata-rata zat organik memperoleh nilai regresi linier 0,9292, sehingga waktu pendidihan berpengaruh sebanyak 92,92\% terhadap kadar zat organik.

\section{Uji Statistik}

Berdasarkan uji normalitas untuk waktu pendidihan selama 5,10 , dan 15 menit diperoleh nilai signifikasi $>0,05$ yang artinya data tersebut berdistribusi normal, maka dilanjutkan dengan uji repeated ANOVA.

Hasil uji repeated ANOVA diperoleh nilai signifikasi sebesar 0,002 , nilai ini $<\alpha(0,05)$ yang artinya ada pengaruh lamanya waktu pendidihan terhadap hasil pemeriksaan zat organik dalam sampel air.

Pada penetapan kadar zat organik dalam sampel air digunakan metode titrimetri yaitu titrasi Permanganometri. Metode ini digunakan untuk penentuan nilai permanganat dengan metode oksidasi suasana asam. Nilai permanganat merupakan jumlah miligram kalium permanganat $\left(\mathrm{KMnO}_{4}\right)$ yang dibutuhkan untuk mengoksidasi zat organik dalam $1000 \mathrm{ml}$ air pada kondisi mendidih. Berdasarkan prinsip dalam penetapannya zat organik dalam sampel air dioksidasi dengan $\mathrm{KMnO}_{4}$ berlebih, kemudian direduksi oleh asam oksalat berlebih. Kelebihan asam oksalat dititrasi kembali dengan $\mathrm{KMnO}_{4}$ (SNI 066989.22-2004, 2004). Berdasarkan prosedur dalam SNI 06-6989.22-2004 lamanya waktu pendidihan untuk penetapan kadar zat organik dalam sampel air adalah selama 10 menit.

Berdasarkan hasil pada tabel 1. dapat dilihat adanya perbedaan kadar zat organik pada waktu pendidihan 5, 10, dan 15 menit. Pada waktu pendidihan selama 5 menit didapatkan hasil sebesar 52,8 mg/L. Hasil ini lebih rendah dari kadar sampel yang telah ditetapkan yaitu $54 \mathrm{mg} / \mathrm{L}$. Berdasarkan prinsip penetapan dalam SNI 06-6989.22-2004 zat organik akan dioksidasi oleh $\mathrm{KMnO}_{4}$ berlebih dengan prosedur lamanya pendidihan selama 10 menit, sehingga dalam waktu pendidihan selama 5 menit ada kemungkinan zat organik yang terdapat didalam sampel air masih belum dioksidasi secara sempurna oleh $\mathrm{KMnO}_{4}$ berlebih dan mengakibatkan hasil yang didapat lebih rendah dari kadar yang seharusnya.

Pendidihan selama 10 menit didapatkan hasil sebesar $54,5 \mathrm{mg} / \mathrm{L}$. Hasil ini sangat mendekati dari kadar yang telah ditetapkan yaitu $54 \mathrm{mg} / \mathrm{L}$. Sehingga berdasarkan prinsip penetapan yang terdapat dalam SNI 066989.22-2004 zat organik dapat dipastikan telah dioksidasi dengan sempurna oleh $\mathrm{KMnO}_{4}$ berlebih dengan lamanya pendidihan yang telah sesuai dengan prosedur yang ditetapkan yaitu 10 menit. 
Pada waktu pendidihan selama 15 menit didapatkan hasil sebesar 55,1 mg/L. Hasil ini lebih tinggi dari kadar yang telah ditetapkan yaitu $54 \mathrm{mg} / \mathrm{L}$. Berdasarkan prinsip penetapan dalam SNI 06-6989.22-2004 zat organik akan dioksidasi oleh $\mathrm{KMnO}_{4}$ berlebih dengan prosedur lamanya pendidihan selama 10 menit, sehingga pada penetapan ini zat organik dapat dipastikan telah dioksidasi dengan sempurna oleh $\mathrm{KMnO}_{4}$ berlebih dikarenakan lamanya pendidihan telah mencapai waktu 10 menit. Namun dari hasil yang didapat, kadar zat organik menjadi lebih tinggi dari yang seharusnya. Menurut Khopkar (2003) $\mathrm{KMnO}_{4}$ dalam air kestabilannya dapat dipengaruhi oleh cahaya, panas, asam-basa, ion $\mathrm{Mn}(\mathrm{II})$, dan $\mathrm{MnO}_{2}$. Dikarenakan zat organik telah habis teroksidasi dan pendidihan masih berlangsung, $\mathrm{KMnO}_{4}$ berlebih yang masih terdapat dalam sampel dapat terganggu kestabilannya. Selama pendidihan yang terus berlangsung $\mathrm{KMnO}_{4}$ berlebih dalam sampel air menjadi tidak stabil dan air teroksidasi dengan cara:

$$
4 \mathrm{MnO}_{4}^{-}+2 \mathrm{H}_{2} \mathrm{O} \longrightarrow 4 \mathrm{MnO}_{2}+3 \mathrm{O}_{2}+4 \mathrm{OH}^{-}
$$

Dengan terjadinya reaksi tersebut $\mathrm{KMnO}_{4}$ yang terdapat dalam sampel menjadi berkurang. Sehingga pada saat penambahan asam oksalat, $\mathrm{KMnO}_{4}$ yang bereaksi dengan asam oksalat akan kurang dari yang seharusnya. Akibatnya asam oksalat yang selanjutnya akan dititrasi dengan $\mathrm{KMnO}_{4}$ menjadi lebih banyak. Hal ini dapat menyebabkan penambahan jumlah $\mathrm{KMnO}_{4}$ yang diperlukan untuk titrasi yang pada akhirnya membuat hasil menjadi lebih tinggi dari yang seharusnya.

Dari penelitian yang telah dilakukan didapatkan perbedaan ketepatan hasil zat organik yang merupakan bagian dari kesalahan sistematika. Untuk mendeteksi kesalahan tersebut maka dilakukan dengan mengamati secara kritis proses pengujian secara keseluruhan yang meliputi diantaranya tahapan metode pengujian termasuk pengendalian mutu internal dengan memastikan bahwa proses pengujian berjalan secara efektif, kondisi instrumen atau alat yang digunakan dalam keadaan baik dan terkalibrasi, kondisi akomodasi dan lingkungan pengujian yang memadai, bahan kimia yang digunakan memenuhi persyaratan teknis, dan analis yang kompeten dalam melakukan pengujian tersebut.

Berdasarkan hasil perhitungan didapatkan hasil \% Bias untuk lamanya pendidihan 5, 10, dan 15 menit secara berurutan yaitu $3,1 \%$;
$0,9 \%$; dan 1,1\%. Berdasarkan hasil tersebut dapat terbukti tingkat ketelitian hasil yang paling baik berdasarkan atas \% Bias adalah pada pendidihan selama 10 menit.

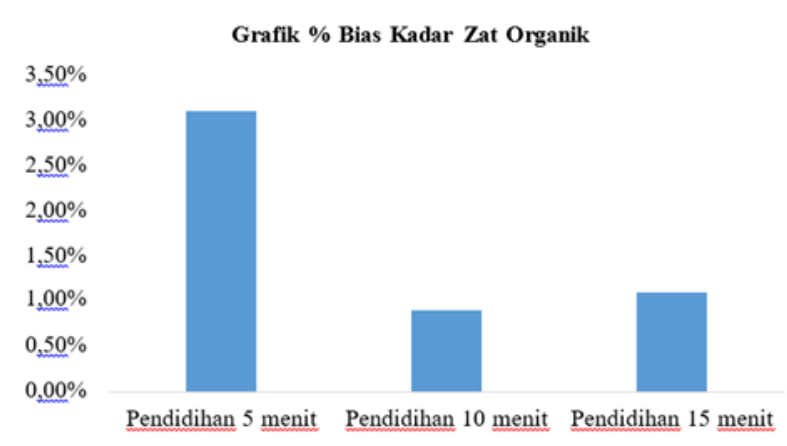

Gambar 1. Hasil perhitungan \% Bias kadar zat organik pada sampel air dengan waktu pendidihan selama 5,10 , dan 15 menit.

Berdasarkan penelitian yang telah dilakukan maka perlu diperhatikan ketepatan dan ketelitian pada proses pendidihan dalam penetapan kadar zat organik sehingga hasil yang dikeluarkan sesuai dengan kondisi sebenarnya. Berdasarkan prosedur dalam SNI 06-6989.22-2004 lamanya waktu pendidihan untuk penetapan kadar zat organik dalam sampel air adalah selama 10 menit, sehingga tidak diperbolehkan untuk tenaga laboratorium melakukan pendidihan dengan waktu kurang dari atau lebih dari 10 menit. Kemudian berdasarkan Permenkes RI No. 416/Menkes/ Per/IX/1990 tentang syarat-syarat dan pengawasan air bahwa kadar zat organik pada air bersih adalah tidak boleh lebih dari 10 $\mathrm{mg} / \mathrm{L}$, oleh karena itu sangat penting untuk air yang akan dikonsumsi harus diolah terlebih dahulu agar dapat dikonsumsi oleh masyarakat dan cara pengolahan yang baik adalah dengan memanaskan air hingga mendidih sehingga kandungan zat organik pada air tersebut dapat berkurang.

\section{KESIMPULAN}

Terdapat pengaruh lamanya waktu pendidihan terhadap ketepatan hasil pemeriksaan zat organik dalam sampel air dengan nilai signifikasi sebesar 0,002 $(<0,05)$. Penentuan ketepatan pemeriksaan zat organik pada waktu pendidihan selama 5,10 , dan 15 menit dengan menggunakan \% Bias secara berurutan yaitu $3,1 \% ; 0,9 \%$; dan $1,1 \%$.

\section{SARAN}

Perlu dilakukan penelitian lebih lanjut dengan menggunakan sampel langsung dari lapangan dengan penambahan matrik sampel. 
DAFTAR PUSTAKA

Asmadi, \& Suharno. (2012). Dasar - Dasar Teknologi Pengolahan Air Limbah. Yogyakarta: Gosyen Publishing.

Day, R. A. J., \& Underwood, A. . (2002). Kimia Analisis Kuantitatif. Jakarta: Erlangga.

Farida. (2006). Pengaruh Suhu Pemanasan Terhadap Penurunan Kadar Zat Organik Jumlah Pada Air Sumur Gali Penduduk Di Kelurahan Dasan Cermen Kecamatan Cakranegara. Poltekkes Kemenkes Mataram.

Febrian, M. B. (2008). Pengembangan Sensor Chemical Oxygen Demand (COD) Berbasis Fotoelektrokatalisis: Evaluasi Respon Terhadap Beberapa Surfaktan. Universitas Indonesia.

Sunawiruddin, H., Budijono, \& Hasbi, M. (2014). Decrease In Organic Substances And H2S With Peat Water Treatment Continuous System For Media Life Goldfish (Cyprinus Carpio). Universitas Riau.

Hanafiah, K. A. (2005). Rancangan Percobaan Teori dan Aplikasi Edisi Revisi. Jakarta: PT Raja Grafindo Persada.

Hidayati, M., Ana, \& Yusrin. (2010). Pengaruh Lama Waktu Simpan pada Suhu Ruang (27-290C) Terhadap Kadar Zat Organik pada Air Minum Isi Ulang. Universitas Muhammadiyah Semarang.

Khopkar, S. M. (2003). Konsep Dasar Kimia Analitik. Jakarta: UI-Press.

Krisma, A. (2008). Penyisihan Besi dan Zat Organik dari Air Tanah Menggunakan Ozon (AOP). Bandung: Institut Teknologi Bandung.

Peraturan Menteri Kesehatan Republik Indonesia No. 416/Menkes/Per/IX/1990. (1990).

SNI 06-6989.22-2004. Air dan air limbah - Bagian 22: Cara Uji Nilai Permanganat Secara Titrimetri. Badan Standarisasi Nasional. (2004). 